\title{
Surveys, distribution and current status of the Madagascar Harrier Circus macrosceles in Madagascar
}

\author{
LILY-ARISON RENE DE ROLAND, RUSSELL THORSTROM, \\ GILBERT RAZAFIMANJATO, MARIUS P.H. RAKOTONDRATSIMA, \\ TOLOJANAHARY R.A. ANDRIAMALALA and THE SEING SAM
}

\begin{abstract}
We conducted a 16-month country-wide survey to determine the status of the threatened Madagascar (Marsh) Harrier Circus macrosceles from 2005 to 2006. We searched for harriers in varying habitat types, focusing on marshes, grasslands and savannas, secondary forests and the edge of primary forests. We surveyed $68 \%$ of the districts of Madagascar which contain $71 \%$ of the potential harrier habitat throughout the country. We recorded 80 individuals of this sexually dimorphic raptor; 48 males and 32 females of which 71 were observed during the breeding season (June to December) and nine outside the breeding season (January to May). The Madagascar Harrier has a broad distribution of about 1,00o km north to south (Madagascar is about $1,500 \mathrm{~km}$ in length) and east to west, but at extremely low density. Fifty-three $(69 \%)$ harriers were observed in high elevation marshes and grasslands above $1,100 \mathrm{~m}$ in the provinces of Mahajanga and Antananarivo during the breeding season. Three major threats to harriers, all human caused, were identified: the transformation of marshes to rice fields (all nests in lower elevation natural marshes), uncontrolled fires destroying nests ( $n=7$ nests lost in 2005 to fires), and human persecution by taking young from nests for a food source and killing adults due to their predatory nature. From our surveys in Madagascar and information from Comoro Islands, we estimate the global population to be $250-500$ individuals suggesting the current Madagascar Harrier population is heading towards endangerment. The survival of the Madagascar Harrier in Madagascar is critically dependent on protecting the remaining natural marshes, which are an extremely limited and critically endangered habitat in Madagascar, with bordering grasslands.
\end{abstract}

\section{Résumé}

En 2005 et 2006, nous avons effectué une expédition afin d'évaluer le statut d'Harrier de Madagascar Circus macrosceles. Durant les 16 mois de terrain, 68\% des districts de Madagascar, contenant approximativement $71 \%$ des habitats susceptibles d'abriter cette espèce, à savoir les marécages, les prairies et les savanes, les forêts secondaires et la bordure de forêt primaire, ont été visités. L'Harrier de Madagascar est une espèce de rapace à dimorphisme sexuel. Nous en avons enregistré 80 individus composés de 48 mâles et 32 femelles. Parmi lesquels, 71 individus ont été répertoriés pendant la saison de reproduction (de juin au décembre), alors que 9 sont rencontrés hors de la saison de reproduction (janvier à mai). On a constaté que l'espèce se rencontre de l'Est à l'Ouest de l'Ile avec une large distribution géographique d'environ $1000 \mathrm{~km}$ du Nord au Sud (la longueur de Madagascar est approximativement égale à $1500 \mathrm{~km}$ ). Toutefois, elle présente une densité extrêmement faible. Cinquante-trois individus (soit 69\%) ont été observés pendant la période de reproduction dans les marécages et savanes de haute altitude, en 
particulier au-dessus de 1,100 $\mathrm{m}$ d'altitude dans les provinces de Mahajanga et d'Antananarivo. Trois principaux types de menace, provenant tous de l'action anthropique, pèsent sur le Harrier de Madagascar: la transformation des marécages en rizières (la plupart des nids sont dans les marécages d'altitude moins élevée), les feux de brousse incontrôlés détruisant les nids des oiseaux (sept nids sont détruits en 2005), la persécution humaine en collectant les poussins dans les nids pour la nourriture et en tuant les adultes à cause de leur nature prédatrice. De cette étude et des informations sur les îles de Comores, nous estimons la taille globale de la population entre 250-500 individus. Par conséquent, nous recommandons de considérer le statut de Circus macrosceles comme étant en danger. En plus, il faut assurer la conservation des marécages encore existants car la survie de la population d'Harrier de Madagascar en dépend. Actuellement, ces zones sont extrêmement restreintes et s'agissent d'habitats gravement menacés à Madagascar.

\section{Introduction}

Twelve of the 24 diurnal and nocturnal raptor species occurring in Madagascar are endemic, and only two are known to be migratory (Thorstrom et al. 2003). Madagascar as a country has the highest percentage of raptor species $(9 \%)$ in the world per total avifaunal diversity which numbers 283 bird species (Morris and Hawkins 1998, Thorstrom et al. 2003). The harrier Circus maillardi macrosceles in Madagascar was split from the Reunion Harrier C. maillardi and designated as a distinctive species - the Madagascar (Marsh) Harrier C. macrosceles in 2000 (Simmons 2000, Wink and Sauer-Gürth 2000). Currently, it is considered a 'Vulnerable' species in Madagascar (BirdLife International 2008). The breeding biology of this species has been studied briefly in Ankazobe (Paverne 1997) and in more detail at Ambohitantely Special Reserve (Randriamanga 2000, Rene de Roland et al. 2004), but the population status and distribution are not well known. This study summarises information collected during a 16-month country-wide survey, including the breeding and non-breeding seasons, the distribution and population density, breeding sites and threats to the Madagascar Harrier.

\section{Study Area}

Perrier de la Bâthie (1921) defined two main regions for flora in Madagascar: the eastern humid forest, corresponding to the windward side, and the western and southern seasonal dry forests on the leeward side. This classification was refined by Humbert and Cours Darne (1965) and later updated by Faramalala (1988, 1995). The national terrestrial ecoregion network is represented by seven regions: northern high plateau, eastern plateau, central plateau, high mountains, western, southern, and the unique isolated or transitional habitats (ANGAP 2001). The study area was split into four ecoregions: eastern $(11,611,177 \mathrm{ha})$, western $(21,104,528 \mathrm{ha})$, central $(17,088,672 \mathrm{ha})$ and north mountain (2,091,011 ha).

Savanna and grasslands make up $69 \%$ of the surface area of Madagascar, whereas marshes $(0.5 \%)$ are extremely limited and a highly-threatened habitat (Inventaire Ecologique Forestier National 1997). The major part of the existing savanna and grasslands were found in the central and western ecoregions. Savannas and grasslands are two different habitat types, but their ecological function is similar. They are inhabited by the same avian species including the Madagascar Harrier. Savannas and grasslands provided foraging habitat while marshes were used for nesting sites by harriers.

We surveyed for Madagascar Harrier throughout Madagascar visiting all six provinces from Ambilobe in the northern province of Antsiranana, Andapa and along the east coast from Maroantsetra to Toamasina in Toamasina province, in the central plateau of the provinces of Antananarivo and Fianarantsoa, from the west coast of Mahajanga province and south to Maintirano, and to Morondava and Fort-Dauphin in the southern province of Toliara (Figure I). 


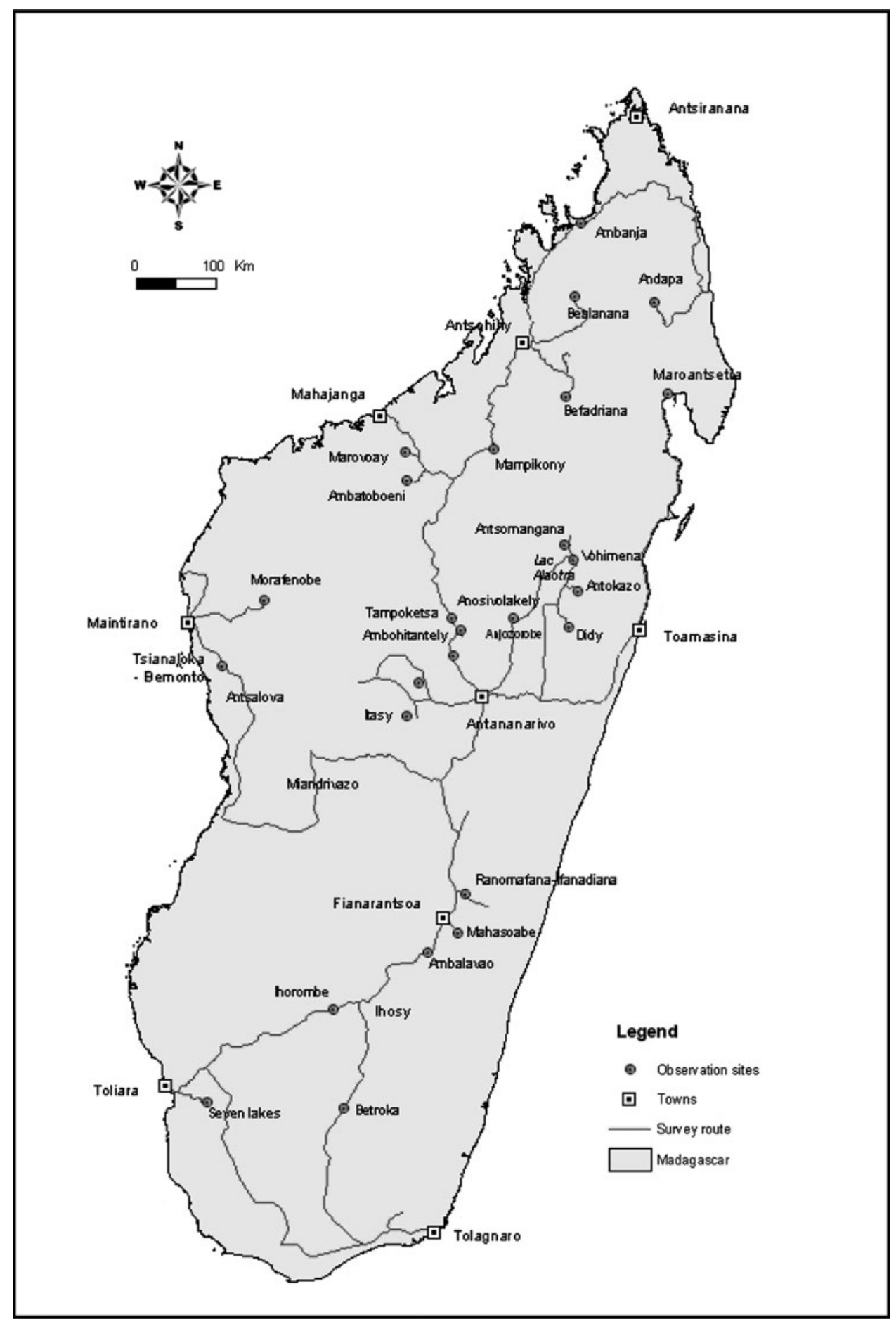

Figure 1. Observation sites and roads travelled during surveys for Madagascar Harrier Circus macrosceles from 2005 to 2006. 


\section{Methods}

Survey route and sites were identified from Foiben-Taosarintanin'i Madagasikara (FTM) 1:500,000 maps. Survey sites were selected two weeks prior to entering the field. During the 16-month survey period in $2005-2006$ we travelled $7,930 \mathrm{~km}$ by vehicle to the existing wetlands, marshes, grasslands and some forests adjacent to wetlands in Madagascar (Figure 1). We spent 1,248 hours searching for harriers along roads, survey sites, and in and around local communities containing possible harrier habitat. Survey time in each province varied, with the maximum effort in Mahajanga province (27 days), followed by Antananarivo ( 18 days), Fianarantsoa (1o days), Toamasina (seven days), Toliara (six days) and Antsiranana (two days). Surveys were conducted by vehicle and on foot at wetlands, savannas, grasslands, rice fields, and secondary forest habitats from April 2005 until July 2006 which covered two breeding seasons and one nonbreeding period. We recorded elevations in metres at each survey site. Daily surveys took place from o7hoo-17hoo. Observers used $10 \mathrm{x}$ binoculars and $20-45 \mathrm{x}$ spotting scopes to identify and observe harriers. Once a harrier was identified, we continued observations to determine the age and sex of the individual. We followed birds until a pair was observed or a nest was located or they disappeared. We recorded the number of individuals and the habitat at each harrier sighting. At each site, excluding Ambohitantely Special Reserve (ASR), we talked with local people to determine their identification skills of harriers with illustrations and photos in Langrand (1990) and from a video we recorded. This helped in identifying sites and areas possibly occupied by harriers.

\section{Results}

During the harrier surveys we encountered three common Malagasy names for the Madagascar Harrier. These names depended on the province, region and local Malagasy dialect in Madagascar: "Fotsiandilana" (a description of the plumage) in the north central region, "Fanindry" (from the harrier's raptorial behaviour) around the capital city Antananarivo, Ankazobe, Lake Alaotra and Itasy regions, and "Fanohoka" (from the harrier's raptorial behaviour) in the southern region.

\section{Madagascar Harrier Surveys}

In total, we surveyed $68 \%$ of the districts at 26 sites throughout Madagascar containing $71 \%$ of savannas/grasslands and wetlands as potential harrier habitat in Madagascar with a concentration in the central eco-region, an area known to have Madagascar Harriers (see Figure 1). During harrier surveys, we recorded three major habitat types where Madagascar Harriers were found: marshes, savannas and grasslands, including fallow rice fields. Marshes were extremely important as nesting sites while savannas and grasslands were important foraging habitat. During surveys in 2005, seven nests were found at Ambohitantely Special Reserve (ASR), in Antananarivo Province. Harriers also used marshes and savannas near the edge of forests, but were absent from marshes bordering lakes with large areas of open surface water. Harriers used fallow rice fields, but were rarely observed in this habitat during the non-breeding season. The size of a marsh and the degree of human activities limited the number of breeding pairs. During the 16-month harrier survey, we observed 45 individuals $(56.3 \%)$ in marshes, 34 individuals $(42.5 \%)$ in savannas and grasslands, and one individual (1.2\%) in rice fields (Table 1; Figure 2). Harriers were significantly tied to habitat type $\left(\chi_{2}^{2}=40.3, P<0.001\right)$.

\section{Mahajanga Province}

We spent 27 days surveying in this large province and had 35 sightings of harriers from Bealanana in the north to the Melaky region in the central western region of Madagascar. 
Table 1. The number of Madagascar Harriers Circus macrosceles observed during 1,248 h of survey time at sites with marshes $(342.2 \mathrm{~h}$ ), savannas and grasslands $(573.7 \mathrm{~h})$, and rice fields $(332.1 \mathrm{~h})$ from 2005 to 2006 in Madagascar.

\begin{tabular}{lccc}
\hline Sites & Marshes & Savannas and grasslands & Rice fields \\
\hline Bealanana & 20 & 2 & - \\
Melaky & - & 11 & - \\
Tampoketsa & 4 & 3 & - \\
Ambohitantely SR & 14 & - & - \\
Itasy & - & - & - \\
Anjozorobe & - & - & - \\
Ambalavao & 3 & - & - \\
Ihorombe Plateau & - & - & - \\
Analanjirofo & 2 & 34 & - \\
Betsiboka & 2 & & 1 \\
TOTAL & 45 & &
\end{tabular}

\section{Bealanana region}

We surveyed this area from 6 to 8 July 2006. We visited seven sites, and all were located in the northwestern part of Bealanana. A total of 22 individuals were recorded, of which 20 individuals were observed in marshes and the surrounding savanna and grasslands, and one pair was reported to us by local people.

Antsahalalina ( $14^{\circ} 27^{\prime} 13.0^{\prime \prime} \mathrm{S}$ and $48^{\circ} 36^{\prime} 49.8^{\prime \prime} \mathrm{E}$; $1,339 \mathrm{~m}$ a.s.l.) is a savanna and one female was observed in flight and appeared to be hunting. At Analavakivoho ( $14^{\circ} 26^{\prime} 27.5^{\prime \prime} \mathrm{S}$ and $48^{\circ} 36^{\prime} 29.0^{\prime \prime} \mathrm{E} ; 1,447 \mathrm{~m}$ a.s.l.) is a marsh near the forest edge of a primary forest. This forest block had a corridor linking the Manongarivo Special Reserve in the northwest and MarojejyTsaratanana. One male was observed flying about $2 \mathrm{~m}$ above the marsh searching for prey. After 30 minutes of observation, one female arrived at the area with a male. We believe this female was probably the individual we recorded at the Antsahalalina site. Local villagers informed us that one pair occupies this area and can be seen frequently during the post-breeding period.

At Bemanevika village ( $14^{\circ} 22^{\prime} \mathrm{o} 8.6^{\prime \prime} \mathrm{S}$ and $48^{\circ} 35^{\prime} 10.1^{\prime \prime} \mathrm{E} ; 1,584 \mathrm{~m}$ a.s.l.) one male was observed in flight near the village. According to local people, this species sometimes visits agricultural fields to search for poultry. At Analadrevaka ( $14^{\circ} 22^{\prime} 05.4^{\prime \prime} \mathrm{S}$ and $48^{\circ} 34^{\prime} \mathrm{O} 8.3^{\prime \prime} \mathrm{E} ; 1,600 \mathrm{~m}$ a.s.l.) is a marsh with one pair. The marsh at Ambatomavo ( $14^{\circ} 21^{\prime} 32.7^{\prime \prime} \mathrm{S}$ and $\left.48^{\circ} 33^{\prime} 25.0^{\prime \prime} \mathrm{E}\right)$ supported five pairs, more than any other sites we visited. At Marotaolana ( $14^{\circ} 20^{\prime} 14.5^{\prime \prime} \mathrm{S}$ and $48^{\circ} 35^{\prime} \mathrm{O} 2.9^{\prime \prime} \mathrm{E}$; $1,658 \mathrm{~m}$ a.s.l.) two pairs were recorded and observed mating. At Ankosilava ( $14^{\circ} 21^{\prime} 10.8^{\prime \prime} \mathrm{S}$ and $48^{\circ} 34^{\prime} 57.6^{\prime \prime} \mathrm{E}$; $1,574 \mathrm{~m}$ a.s.l.), along the road between Bemanevika and Marotaolana, one female was observed flying above the grasslands, and local people mentioned the existence of one resident pair at this site. At this site we documented one pair being predated on by humans.

\section{Betsiboka region $\left(16^{\circ} 27^{\prime} 25 \cdot 7^{\prime \prime} \mathrm{S}\right.$ and $46^{\circ} 45^{\prime} 19 \cdot 5^{\prime \prime} \mathrm{E} ; 20 \mathrm{~m}$ a.s.l.)}

We visited wetland areas around Ambato-Boeni district and Madirovalo Commune, and we observed only two adult males. Local people said harriers used to be more abundant around Madirovalo, and now they are rare. Almost all wetlands have been transformed into agricultural fields in this region. This site was surveyed during the non-breeding period in March 2006, and we suspect a minimum of two pairs in this area.

\section{Melaky region}

We surveyed from Besalampy to Antsalova passing at Morafenobe $\left(17^{\circ} 51^{\prime} 07 \cdot 3^{\prime \prime} \mathrm{S}\right.$ and $44^{\circ} 55^{\prime} 22.1^{\prime \prime} \mathrm{E} ; 233 \mathrm{~m}$ a.s.l.) and Maintirano areas. We observed four adult males, and two pairs 


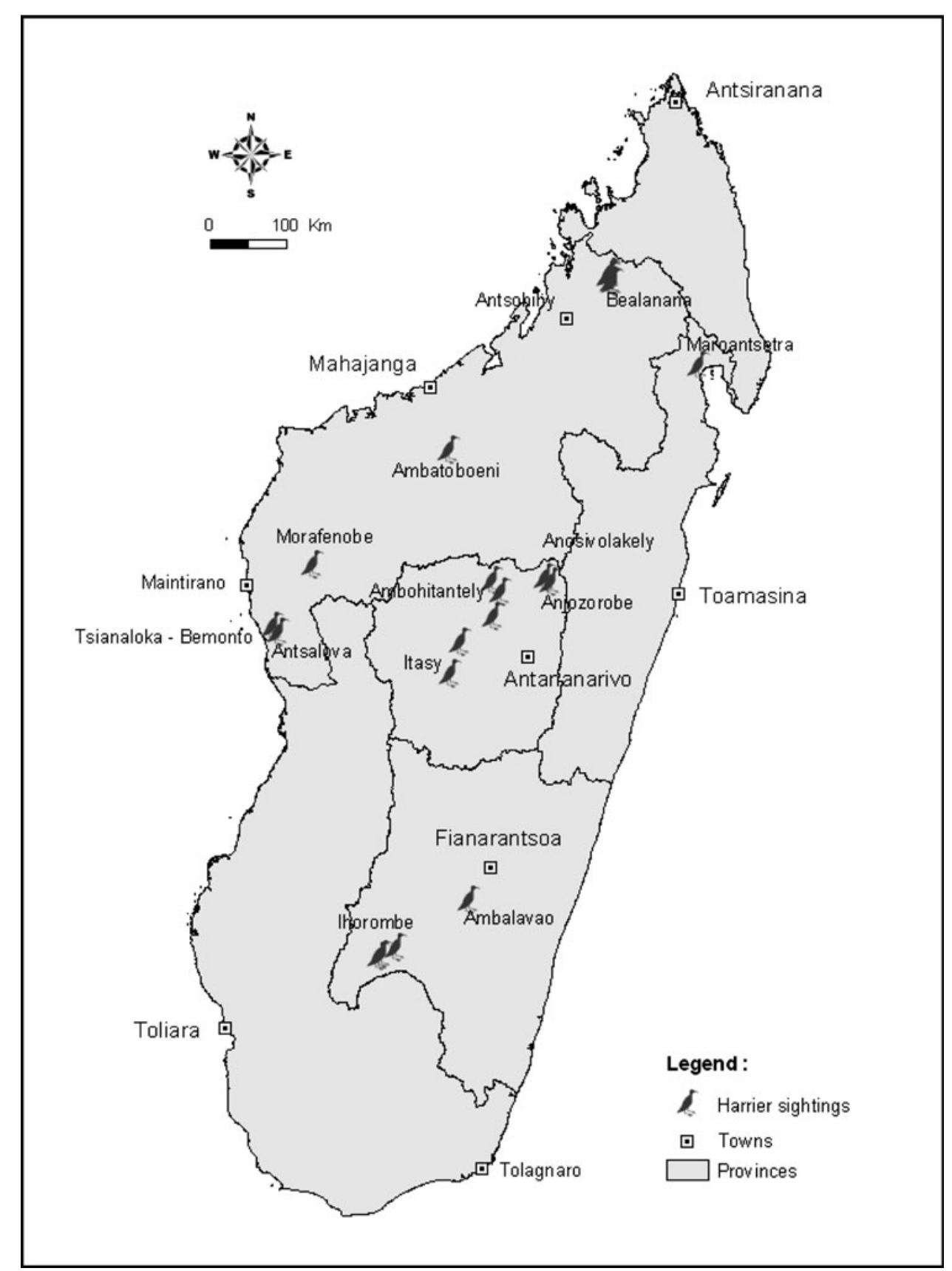

Figure 2. Sightings of Madagascar Harriers Circus macrosceles in the six provinces of Madagascar from 2005 to 2006.

in this region which is made up mostly of savannas near sea level. All individuals observed here appeared to be pairs, and the survey occurred during the breeding season from August to September 2005. We estimate that a minimum of six pairs may inhabit this area as we believe the adult females may have been on nests. 
Marovoay wetland region ( $16^{\circ} 28^{\prime} 17.2^{\prime \prime} \mathrm{S}$ and $46^{\circ} 44^{\prime} 50.9^{\prime \prime} \mathrm{E} ; 17 \mathrm{~m}$ a.s.l.)

We surveyed around Marovoay during February 2006. We did not detect any harriers in this area. Nearly all the marshes have been transformed into rice fields, and the other habitats in the area were all modified by human activity too.

\section{Befandriana Avaratra region}

We surveyed this region on 17 July 2006. The landscape at this site appeared similar to the Bealanana region to the north. The local communities were able to describe harriers and plumages of males and females. Villagers in Ambararata confirmed the presence of harriers, but said it was rare in the area. We visited one locality named Tsarahonenana ( $15^{\circ} 28^{\prime} 51.6^{\prime \prime} \mathrm{S}$ and $48^{\circ} 29^{\prime} 27.8^{\prime \prime} \mathrm{E} ; 383 \mathrm{~m}$ a.s.l.) and its surrounding marshes, but did not observe any harriers.

\section{Mampikony region ( $16^{\circ} \mathrm{O} 8^{\prime} 29 \cdot 7^{\prime \prime} \mathrm{S}$ and $47^{\circ} 37^{\prime} 17 \cdot 1^{\prime \prime} \mathrm{E} ; 77 \mathrm{~m}$ a.s.l.)}

We surveyed the wetland habitat of Mampikony region on 4 July 2006. We did not observe any Madagascar Harriers. One individual near the wetlands in Mampikony region was observed during 2000 (Rabenandrasana pers. comm.). This report suggests this region may support harriers, but they may be gradually disappearing because we did not record any individuals during our surveys. The principal threat to the wetlands is conversion of marshes for rice cultivation.

\section{Antananarivo Province}

We spent 18 days surveying for harriers in this central plateau province and recorded 30 individual harriers.

Tampoketsa region ( $18^{\circ} \mathrm{OO}^{\prime} 44.2^{\prime \prime} \mathrm{S}$ and $47^{\circ} \mathrm{Og}^{\prime} 14.5^{\prime \prime} \mathrm{E} ; 841 \mathrm{~m}$ a.s.l.)

On 2 July 2006, we surveyed along the road towards Mahajanga from Antananarivo from Ankazobe to Mahatsinjo. Two pairs and three individuals were observed in this region. The two pairs were at different marshes, and most likely near their breeding sites. The three individuals were observed flying, and possibly foraging in the area too. We estimated five pairs in this area.

\section{Ambohitantely Special Reserve ( $18^{\circ} 09^{\prime}-18^{\circ} 14^{\prime} \mathrm{S}$ and $47^{\circ} 17^{\prime} \mathrm{E} ; 1,550-1,660 \mathrm{~m}$ a.s.l.)}

This area is well known for breeding harriers in Ankazobe (Paverne 1997) and Ambohitantely Special Reserve (ASR) (Randriamanga 2000, Rene de Roland et al. 2004). Both surveys were conducted during the breeding season and both sites are not far from Antananarivo, the capital. The marshes at these two sites are important for nesting habitat, and ASR is a protected area. We observed seven pairs with nests during our surveys at ASR in November 2005, but all nests were destroyed by a wildfire during the incubation and nestling period. We resurveyed this site in January 2006 and found two pairs attempting to nest again, but both nests were predated by humans. ASR is the most important breeding site for harriers in the Antananarivo Province. We also recorded one individual near Ankazobe during the first survey.

\section{Itasy region ( $19^{\circ} \mathrm{O} 8^{\prime} 11.8^{\prime \prime} \mathrm{S}$ and $46^{\circ} 37^{\prime} 50.5^{\prime \prime} \mathrm{E} ; 1,221 \mathrm{~m}$ a.s.l.)}

We surveyed from Arivonimamo to Tsiroanomandidy in the west, and to Soavinandriana area in the south. We observed six harriers, comprising one pair and four males in savanna and grassland habitat in June 2006. 
Anjozozorobe Anosivolakely region ( $18^{\circ} 13^{\prime} 41.1^{\prime \prime} \mathrm{S}$ and $47^{\circ} 15^{\prime} 40.1^{\prime \prime} \mathrm{E} ; 1,071 \mathrm{~m}$ a.s.l.)

We believe harriers only used this area for foraging. We observed three adult males during the non-breeding period in April 2005: one was observed flying above a fallow rice field and the other two were observed flying over savanna habitat about three metres above the ground. Local people reported that this species was more abundant during the non-breeding season, but absent during the breeding period. This is useful data to determine where harriers go when non-breeding.

\section{Fianarantsoa Province}

We surveyed for 10 days in this province and had 13 sightings of harriers from Ambalavao in the north to Ihorombe Plateau in the south.

Ambalavao region $\left(21^{\circ} 52^{\prime} 55 \cdot 36^{\prime \prime} \mathrm{S}\right.$ and $\left.46^{\circ} 54^{\prime} 44.87^{\prime \prime} \mathrm{E} ; 985 \mathrm{~m}\right)$

We visited this 140,639 ha area during the non-breeding season in February 2006 and saw many marshes and savannas, but we observed only one adult male. A local guide mentioned there were two pairs in these marshes during the breeding period. We suspect Madagascar Harriers use this area all year.

Ihorombe Plateau region $\left(22^{\circ} 29^{\prime} 5 \mathrm{O} .86^{\prime \prime} \mathrm{S}\right.$ and $\left.46^{\circ} \mathrm{O}^{\prime} \mathrm{O} 4.21^{\prime \prime} \mathrm{E} ; 1,112 \mathrm{~m}\right)$

We visited this area during the breeding and non-breeding season, respectively in October 2005 and again in February 2006. This area is formed by the existence of a large savanna plateau $40 \mathrm{~km}$ in length. During the breeding season, we observed seven individuals consisting of possibly three pairs and one sub-adult, and during the non-breeding season we recorded three individuals, two males and one female.

Mahasoabe $\left(21^{\circ} 37^{\prime} 25 \cdot 32^{\prime \prime} \mathrm{S}\right.$ and $\left.47^{\circ} 14^{\prime} 49.13^{\prime \prime} \mathrm{E} ; 1,109 \mathrm{~m}\right)$

After discussion with local communities, we believe harriers exist in this area as people were able to describe the distinctive characteristics and flight behaviour of harriers. We surveyed this site on November 2005, but did not observe any harriers. This area has several natural marshes and grasslands which are suitable habitat for harriers, and probably used by them during the breeding season.

Ranomafana-Ifanadiana region $\left(21^{\circ} 10^{\prime} 17 \cdot 9^{\prime \prime} \mathrm{S}\right.$ and $\left.47^{\circ} 20^{\prime} 31.4^{\prime \prime} \mathrm{E} ; 1,085\right)$

We surveyed the secondary forest and all the marshes in proximity to the rainforest habitat during April 2006, the non-breeding season. We did not observe harriers here. We continued observations up to Ifanadiana, and then around to Ambohimasoa town with no sightings. In addition, the local communities and people did not know this species.

\section{Toamasina Province}

We surveyed for seven days in this province and had two sightings of harriers near Maroantsetra.

\section{Analanjirofo region}

We surveyed from Soanierana Ivongo to Maroantsetra. We observed very few marshes except near Maroantsetra. Most of the habitat was primary or degraded forests in this region. We observed one pair at Maroantsetra, in open habitat, close to the airport $\left(15^{\circ} 26^{\prime} 08^{\prime \prime} \mathrm{S}\right.$ and 
$49^{\circ} 4 \mathrm{I}^{\prime} 22^{\prime \prime} \mathrm{E} ; 69 \mathrm{~m}$ a.s.l.) flying about $2 \mathrm{~m}$ above ground searching for food. We believe a larger area is suitable for harriers in this region.

Alaotra Lake region $\left(17^{\circ} 38^{\prime} 31.9^{\prime \prime} \mathrm{S}\right.$ and $\left.48^{\circ}{ }^{\circ} 5^{\prime} 06.7^{\prime \prime} \mathrm{E} ; 997 \mathrm{~m}\right)$

The area around Alaotra Lake was surveyed during October 2005. We did not observe any harriers, but local people mentioned harriers as being rare and seasonal in the north around Vohimenakely up to Antsomangana and Ampamoho and to the south of Andilamena. Along the road between Alaotra Lake and Anjozorobe we talked with the local people, described the harrier's characteristics to them and showed them pictures of the bird. Some reported seeing harriers only in February, but never observed birds nesting in their area. This region does not appear to have adequate habitat for Madagascar Harriers. South and east of Alaotra Lake, harriers are not known by the local people and we did not encounter them during surveys.

\section{Antsiranana Province}

We surveyed this province for two days. We had no observations or information on harriers in this northernmost province.

\section{Ambanja region}

The survey occurred on 9 July 2006 at Ankinaka ( $13^{\circ} 29^{\prime} 54.6^{\prime \prime} \mathrm{S}$ and $\left.48^{\circ} 38^{\prime} 17.8^{\prime \prime} \mathrm{E}\right)$ site was along the road to Ambilobe with an altitude of $15 \mathrm{~m}$. No individuals were recorded during surveys. We believe this site may have been inhabited by harriers in the past, but due to human activities, disturbances and habitat conversion of marshes into rice fields, the harriers were either extirpated or moved out of the area.

\section{Andapa region}

The surveyed area was Doany ( $14^{\circ} 23^{\prime} 16.8^{\prime \prime} \mathrm{S}$ and $\left.49^{\circ} 30^{\prime} 47 \cdot 9^{\prime \prime} \mathrm{E}\right)$ and is located west of the town of Andapa. It is composed of savanna habitat at an altitude of $48 \mathrm{~m}$. This site was surveyed on II July 2006. Part of the savanna and surrounding wetlands were visited but no individuals were recorded. Interviews with local people report its absence around this locality. In general, the villagers reported never seeing this species in their area. In addition, all existing marshes (21,378 ha) were converted into rice paddies ( $100 \%$ loss) due to the human demographic increase into the area in the past few decades.

\section{Toliara Province}

We surveyed for six days in this province during November 2005. We had no observations or information on harriers in this southernmost province.

\section{Betroka $\left(23^{\circ} 37^{\prime} 07.15^{\prime \prime S}\right.$ and $45^{\circ} 5^{\prime}$ o9.18' $\left.{ }^{\prime \prime} ; 742 \mathrm{~m}\right)$}

In November 2005, we surveyed south of Betroka along the road from Ambovombe to Ihosy. This area contained habitat that appeared good for harriers. One local guide confirmed the presence of this bird during the breeding season. This person was able to describe the difference between the two sexes and its behaviour, but we did not observe any harriers at this site.

In total, 80 individual Madagascar Harriers were observed throughout Madagascar of which 69 and $I I$ individuals were observed during the breeding and non-breeding seasons, respectively. 
Two provinces, Mahajanga and Antananarivo, had the highest number of harriers with 35 and 30 individuals recorded, respectively (Figure 2). In Toamasina province, we observed only two individuals. Ihorombe Plateau in Fianarantsoa Province had exceptional harrier habitat and we observed 13 individuals there (Table 2). We did not observe harriers in two provinces: Antsiranana and Toliara. Among the 80 individuals we documented 48 males and 32 females.

\section{Discussion}

Historically, the Madagascar Harrier has been reported as not very common throughout the island (Delacour 1932) and as an uncommon bird of the open marshes and neighbouring grasslands of the eastern humid ecoregion and marshes and damper grasslands of the western ecoregion (Rand 1936). Rand (1936) also reported that harriers were found to be rather common over a marsh at the head of Lac Ihotry in December 1929 and over a marsh near Vohémar in September 1931. These two sightings by Rand (1936) are most likely from a nesting area where harrier activity is frequent and easily observable, making them appear to be more common than they actually are. Recently, its presence and distribution in Madagascar has been described as inexplicably uncommon (Langrand and Meyburg 1984), thinly distributed (Langrand 1990), only observed on a few occasions in the southeast (Goodman et al. 1997), widely distributed in suitable habitat but uncommon (Morris and Hawkins 1998), and uncommon and infrequently observed (Thorstrom et al. 2003, P. Morris pers. comm. 2008). Presently, the Madagascar Harrier is a relatively rare raptor found throughout the island, but even in its preferred habitat of marshes, wetter grasslands and savannas it is rarely observed except during the breeding season in this mosaic habitat. Our observations of 80 individuals during the 16-month survey period showed Madagascar Harriers to be an extremely rare bird with a very low population density throughout Madagascar, and as Simmons (2000) pointed out, island species of harriers often exhibit very small populations with a greater chance of becoming extinct. In the last 12 years, harriers have become increasingly rare to disappearing from the Vohiparara marshes, Ihorombe Plateau and the road between Antananarivo and Mahajunga (P. Morris pers. comm. 2008). The greater number of males observed during our surveys may be due to the male's increased activity and responsibility during the breeding season in defending nesting territories and providing food for incubating and brooding females and nestlings. During the non-breeding season, the distinctive plumage of males makes them more visible than the cryptic plumage of females.

Harriers on the Comoro Islands archipelago, consisting of four major islands $300-500 \mathrm{~km}$ northwest of Madagascar with a total surface area of $2,236 \mathrm{~km}^{2}$, appear to be indistinguishable from the Madagascar Harrier (Simmons 2000). The harrier population on the four islands is estimated at 50-250 individuals and they are described as common on Anjouan and Moheli, but very rare on Grand Comore and extremely rare to extinct on Mayotte, the closest island to Madagascar (Louette 2004, M. Louette pers. comm. 2008, R. Safford pers. comm. 2008, P. Morris

Table 2. The number of Madagascar Harriers Circus macrosceles observed within the six provinces during surveys from 2005 to 2006.

\begin{tabular}{lccr}
\hline PROVINCE & Breeding (June-December) & Non-breeding (January to May) & Total \\
\hline Antsiranana & - & - & 0 \\
Mahajanga & 33 & 2 & 35 \\
Toamasina & 2 & - & 2 \\
Antananarivo & 27 & 3 & 30 \\
Fianarantsoa & 7 & - & 13 \\
Toliara & - & 11 & 80 \\
TOTAL & 69 & \\
\hline
\end{tabular}


pers. comm. 2008). The population on the Comoro Islands is most likely similar in size to the population on Madagascar, which has a surface area of $587,041 \mathrm{~km}^{2}-260$ times larger. It would be interesting to know why there is a distinct difference in harrier densities between Madagascar, with an extremely low density throughout the country despite nearly three-quarters of the country composed of savanna and grassland habitat, and the Comoro Islands with a small surface area and a high harrier density among a high human population density. Harriers in Madagascar are definitely dependent on marshes for breeding whereas the harriers in the Comoro Islands are associated with all habitat types, and are even found over closed-canopy forests, a trait similar to the Reunion Harrier C. maillardi, a sister species which also has a high density (Bretagnolle et al. 2000, Louette 2004, R. Safford pers. comm. 2008). Maybe there is a genetic difference between these two subpopulations on Madagascar and the Comoro Islands?

All of the world's marsh harriers are found in wetlands with reeds and open water (Simmons 2000), but the Madagascar Harrier is less typical in that it occupies natural marshes and waterinundated grasslands for nesting, bordered by extensive drier grasslands and savannas for foraging (Paverne 1997, Randriamanga 2000, Rene de Roland et al. 2004), but in the Comoro Islands, where marshes are nonexistent, they appear to nest on the ground in dry grasslands (Louette 2004). Madagascar Harriers also used marshes and savannas near the edge of forests, but were absent from marshes bordering lakes with large areas of open water. We suspect persecution and other human activities, such as fishing and conversion of shallow lake shores into rice paddies, deterred them from using these areas or impacted on their use in some way.

The most important habitat requirements for this species are undisturbed marshes, like those found at Ihorombe Plateau, Ambohitantely Special Reserve (ASR), and Bealanana, and savannas and grasslands. Without this combination of important habitat types, harriers are absent. The remarkable breeding density of this species in ASR and Bealanana is due to the unique habitat characteristics of these two sites: high elevation marshes, a low human population density and limited wetland degradation (Randriamanga 200o, L.-A. R.d.R. pers. obs.). In Bealanana, there are very few humans living in the area and none of the wetlands have been altered or subjected to uncontrolled fires for decades and this has allowed harriers to reproduce naturally at this site. Whereas in ASR, there is a good mixture of marshes and grasslands within a protected area which has allowed harriers some degree of protection for breeding, but there are high incidences of human-caused wildfires which have destroyed harrier nests in the past (Randriamanga 2000, L.-A. R.d.R. pers. obs.).

We believe elevation has an important role in the existing distribution of harriers in Madagascar. The breeding density at higher elevation marshes of Bealanana and ASR is interesting because we suspect they have most likely retreated to these areas due to the lack of low elevation wetlands and limited human activities. Also, nearly, if not all, lower elevation wetlands have been transformed or altered in Madagascar. The cultivation of rice in higher elevation wetlands is not practical because the colder ambient temperature inhibits rice growth. This has resulted in wetland habitats at higher elevations being utilized less by humans, and leaving natural marshes undisturbed as harrier nesting habitat.

Harriers are more obvious during the breeding season where they are active around marshes in establishing or defending nesting areas and delivering food. Some species have different seasonal or annual habitat needs, whereas others require different habitats for feeding and nesting during the same season (Newton 1979). This was observed for Madagascar Harriers during our surveys. While harriers were observed year-round at Bealanana and Ihorombe Plateau, this differed from ASR where they were not present and appeared to move out of the area during the non-breeding season. This movement may be due to seasonal climatic changes from higher elevation wetlands during the breeding season (dry period) to remote lower marshes and grasslands away from human activity in the non-breeding (rainy and colder season) period. The change in weather may reduce prey availability for harriers, also leading to this movement.

The major threats to Madagascar Harriers are conversion of marshes into rice fields, uncontrolled fires in savanna and grasslands, and collection of young from nests for human 
consumption. Nearly all marshes in Madagascar have been transformed into rice fields, especially in areas with dense human populations at low to mid elevations. The conversion of marshes and wetlands into rice fields has occurred since man arrived in Madagascar (Muttenzer 2006), but it has drastically accelerated during the last three decades (Moreau 2006). In fact, wetland habitat, including marshes, has declined by 60\% between 1965 (697,00o ha) and $1996(279,000$ ha), and grassland/savanna habitat by nearly the same amount (Dufils 2008). Considering this $60 \%$ decrease in vital nesting and foraging habitats for harriers up to more then a decade ago, and most likely greater now, one would suspect a similar proportional reduction in the Madagascar Harrier population. Without reproduction there can be no recruitment to the breeding population.

In Madagascar, nearly all fires in grasslands and savannas occur in the dry season from August to November, which is also the harrier breeding season. In one incident during the 2005 breeding season, seven nests at ASR were destroyed by a wildfire. This threatens not only ASR and harriers but other wildlife and biodiversity in the grassland and savanna habitats throughout most of the country too. Between $I$ and 3 million ha of grasslands and savannas in Madagascar are burned each year, including marsh habitat surrounding savannas, and this does not include fires set intentionally and left unmanned (Gilles 2002, L.-A. R.d.R. pers. obs.). We believe uncontrolled human-caused fires are the greatest threat to harriers throughout Madagascar. Savannas, grasslands and marshes are burned to stimulate new grass and fodder mainly for cattle grazing, but also for land clearance and agriculture. Another threat to harriers is adults and young are persecution for food and potential threat to free-ranging poultry in villages. During the 16-month survey, we recorded young from three pairs, one of nine nesting pairs in Bealanana and two of seven nesting pairs in ASR, predated on by humans. Young raptors are generally heavier than adults before fledgling (Newton 1979), and this makes the young more desirable to local villagers as a source of food. Additionally, harrier nests are placed on grass tussocks in shallow water in marshes, making them easily accessible to humans (Rene de Roland et al. 2004).

\section{Conclusions}

The Madagascar Harrier is a poorly-known raptor in Madagascar. The harrier has a broad distribution throughout the country, but occurs at very low population density making it a difficult species to study. During this study, we documented 80 individuals in approximately $71 \%$ of the savanna and grassland habitats throughout Madagascar. Since we could not survey all suitable harrier habitat, we estimated the harrier population to be $2-3$ times our figure, that is $50-$ 250 individuals, provided that $100 \%$ of the habitat is suitable and occupied by Madagascar Harriers, which is highly unlikely. If we regard the two Madagascar Harrier subpopulations as the same taxon, with numbers in the Comoro Islands estimated at 50-250 individuals and in Madagascar at 150-250, this would result in a global population of 200-500 individuals. Currently, the Madagascar Harrier is classified as 'Vulnerable' on the 2008 IUCN Red list under criteria $\mathrm{C}_{2} \mathrm{a}(\mathrm{i})$ and $\mathrm{D}$ ( (population estimate of 250-999 individuals, a declining population, more than one subpopulation, but with the largest subpopulation numbering $>250$ individuals; BirdLife International 2008), but these criteria also suggest this species is bordering on 'Endangered' status. Since the Madagascar and Comoro Islands harrier populations show different habitat needs, densities and behaviours there is the possibility they are different genetically. There is also the possibility that the distribution of harriers on Madagascar is so fragmented that there is in fact more than one subpopulation on the main island. It may be that further work will lead to the recommendation that the species requires uplisting to 'Endangered' following the same IUCN red list criteria, C2a(i) and D (IUCN 2001).

In Madagascar, natural marshes that Madagascar Harriers require for nesting are a critically endangered habitat. The low number of harriers we observed in Madagascar reflects the lack of natural marshes to support nesting sites. We believe the Bealanana region should be classified as a protected area for Madagascar Harriers, especially due to the threats to wetlands and their limited numbers in Madagascar. As most of the protected areas in Madagascar are for forested 
habitat, except small areas like in Ambohitantely Special Reserve, the protection of harriers must include nesting as well as foraging habitat found in grasslands and savannas. There is a great need to protect marshes, savannas and grasslands in order to protect this unique species. Raising public awareness in local communities regarding the negative impact of fire practices needs to be addressed for harrier conservation. It is also important to conduct surveys and research on harriers in the Comoro Islands, $300 \mathrm{~km}$ to the northwest, in order to understand their status and relationship to the harriers in Madagascar; if the two populations are taxonomically distinct then their global conservation status would need to be re-evaluated.

\section{Acknowledgements}

This study was supported by funding from Conservation International-Madagascar and The Peregrine Fund. We thank the Ministry of Environment, Water and Forest, and ANGAP for their continued collaboration with The Peregrine Fund's Madagascar Project and their role in conservation in Madagascar. We also would like to thank the technical services of the Department of Water and Forest, ANGAP staff and local communities at the sites we visited. We thank Michael Louette, Roger Safford, Pete Morris, Stuart Marsden and Stuart Butchart for their advice and comments.

\section{References}

ANGAP (2001) Plan de gestion national des aires protégées de Madagascar 2001-2006. Antananarivo: ANGAP.

BirdLife International (2008) Species factsheet: Circus macrosceles. BirdLife International. Available at: http://www.birdlife.org. Accessed on: 29 October 2008.

Bretagnolle, V. Ghestemme, T., Thiollay, J.-M., and Attié, C. (2000) Distribution, population size and habitat use of the Réunion Harrier, Circus m. maillardi. J. Raptor Res. 34: 8-17.

Delacour, J. (1932) On the birds collected in Madagascar by the Franco-Anglo-American Expedition, 1929-1931. Ibis 13: 284-304.

Dufils, J.-M. (2008) Couvert forestier restant. Pp. 67-79 in S. M. Goodman, ed. Paysages naturels et biodiversité de Madagascar. Paris: Musée National d'Histoire Naturelle.

Faramalala, M. H. (1988) Etude de la végétation de Madagascar à l'aide des données spatiales. Thèse de Doctorat. Toulouse: Université de Paul Sabatier.

Faramalala, M. H. (1995) Formations végétales et domaine forestier national de $\mathrm{Ma}$ dagascar. Antananarivo: CI, DEF, CNRE, FTM.

Gilles, B. (2002) Food security in Madagascar: a situation analysis. Washington, DC: Food \& Nutrition Technical Assistance Project. Academy for Educational Development.
Goodman, S. M., Pidgeon, M., Hawkins, A. F. A., and Schulenberg, T. S. (1997) The birds of southeastern Madagascar. Fieldana - Zoology 87: 1-132.

Humbert, H., and Cours Darne, G. (1965) Carte internationale $d u$ tapis végétal et des conditions écologiques. 3 coupures au 1/1,000,000 de Madagascar. Pondichery: Travaux de la Section Scientifique et Technique de l'Institut Français de Pondichery (hors série).

Inventaire Ecologique Forestier National (1997) Carte de la végétation de Madagascar, I/I,000,000. Antananarivo: FoibenTaosarintanin'i Madagasikara.

IUCN (2001) IUCN Red List Categories and Criteria: Version 3.1. Gland, Switzerland and Cambridge, UK: IUCN Species Survival Commission.

Langrand, O. and Meyburg, B.-U. (1984) Birds of prey and owls in Madagascar: their distribution, status and conservation. Pp. 3-13 in J. M. Mendelsohn and C. W. Sapsford, eds. Proc. Second Symp. African Predatory Birds. Durban: Natal Bird Club.

Langrand, O. (1990) Guide to the birds of Madagascar. New Haven, USA: Yale University Press.

Louette, M. (2004) Oiseaux. Pp. 83-196 in M. Louette, D. Meirte, and R. Jocqué (eds). La faune terrestre de l'archipel des Comores. 
Tervuren, Belgium: Musée Royal de l'Afrique Centrale. Studies in Afrotropical Zoology vol. 293.

Moreau, S. (2006) Les territories de la forêt: présentation simplifiée de la communication au colloque Gecorev. $\mathrm{C}_{3} \mathrm{ED}$, USQV, Juin 2006.

Morris, P. and Hawkins, F. (1998) Birds of Madagascar: a photographic guide. New Haven, USA: Yale Univ. Press.

Muttenzer, F. (2006) Défretatin et droit coutumier à Madagascar. L'historicité d'une politique foncière. Genève: Thèse Dctorat Faculté des Scenes Economiques et Sociales. Institut Universitaire d'Etude du Développement. Université de Genève.

Newton, I. (1979) Population ecology of raptors. Vermillion, USA: Buteo Books.

Paverne, L. (1997) Nidification et comportement du Busard de Maillard (Circus maillardi) dans la region d'Ankazobe au nord-ouest d'Antananarivo. Working Group on Birds in the Madagascar Region Newsl. 7: 21-24.

Perrier de la Bâthie, H. (I921) La végétation malgache. Annales de l'Institut BotanicoGéologique de Marseille (Série 3) 9: 1-226.

Rand, A. L. (1936) The distribution and habits of Madagascar birds. Bull. Am. Mus. Nat. Hist. 72: 143-499.
Randriamanga, I. (2000) Contribution à l'étude de la biologie de la reproduction et écologie de Busard de Madagascar Circus macrosceles dans le Tampoketsa d'Ankazobe. Antananarivo: Mémoire de D.E.A. Faculté des Sciences, Université d'Antananarivo.

Rene de Roland, L.-A., Rabearivony, J., Randriamanga, I. and Thorstrom, R. (2004) Nesting biology and diet of the Madagascar Harrier (Circus macrosceles) in Ambohitantely Special Reserve, Madagascar. J. Raptor Res. 38: 256-262.

Simmons, R. E. (2000) Harriers of the world: their behaviour and ecology. Oxford, UK: Oxford University Press.

Thorstrom, R., Rene de Roland, L.-A. and Watson, R. T. (2003) Falconiformes and Strigiformes: ecology and status of raptors. Pp. 1080-1085 in S. M. Goodman and J. P. Benstead, eds. The natural history of Madagascar. Chicago, U.S.A., and London, UK: University of Chicago Press.

Wink, M. and Sauer-Gürth, H. (200o) Advances in molecular systematics of African Raptors. Pp. 135-147 in R. D. Chancellor and B. U. Meyburg, eds. Raptors at risk. Surrey, Canada: Hancock House.

LILY-ARISON RENE DE ROLAND, GILBERT RAZAFIMANJATO, MARIUS P.H. RAKOTONDRATSIMA, TOLOJANAHARY R.A. ANDRIAMALALA, THE SEING SAM

The Peregrine Fund's Madagascar Project, B.P. 4113, Antananarivo, Madagascar

RUSSELL THORSTROM*

The Peregrine Fund, 5668 West Flying Hawk Lane, Boise, Idaho U.S.A.

*Author for correspondence; email: rthorstrom@peregrinefund.org

Received 25 March 2008; revision accepted 8 December 2008 